\title{
Gender Differentials in Rural Households' Food Securitycoping Strategiesin South-WesternNigeria
}

\author{
Falowo O.O and G.M Adebo \\ Department of Agricultural Economics and Extension, Federal University of Oye Ekiti,Ekiti State, Nigeria \\ Department of Agricultural Economics and Extension Services, Ekiti State University,Ado Ekiti,Nigeria
}

\begin{abstract}
The study was carried out to investigate gender differences in rural households' food security coping strategies in South-Western Nigeria. A multi stage sampling technique was used in selecting 252 respondents utilized for the study. A well-structured questionnaire was used to elicit information from them. The result shows that the females were older than the male with a mean age of 50 and 45 years respectively. Most of the male respondents were married as against the females. There were more divorced/separated, widowed and cohabiting women than men. The male respondents have larger household sizes than the females. Although a higher proportion of both genders were literate, the literacy level of the male gender was higher than that of the females. While most of the respondents were farmers, the study shows heterogeneity of occupation which contradicts the assumptions of the rural people as a homogeneous group. The male households were more food secure than the female households. Though the consumption of less expensive food was ranked first among both genders, there are wide variations in the food security coping strategies utilized. Some top coping strategies utilized by the male gender includes rationing money had to buy prepared food and migration to cities and towns while those of the female gender include occupation diversification/ multiple jobs, purchase of food on credit and the sale of assets such as land and jewelries. The female genders were more hit by food insecurity than their male counterparts. The study recommends the recognition of heterogeneous marital status of the female gender and occupational diversity in food security interventions. It is germane to intensify education of rural dwellers on family planning. Strategic policies on food security in Nigeria should be based on gender.
\end{abstract}

Key words:Adoption, Coping strategies, Distinction, Food security, Gender

\section{Introduction}

Food is a nourishing substance that is eaten or taken into the body to sustain life, provide energy, or promote growth. It is a basic human necessity; hence its availability poses a great challenge to man's existence. Food insecurity according to IFAD (2013) is not a new challenge for Africa because the continent has struggled with hunger and food insecurity for over twenty years. According to FAO (2014a) report, almost 33 percent of the African population is malnourished. UNECA (2012), also stated that about 239 million (30 percent of Africa's total population) of the total of the world's 1 billion undernourished live in Africa. A high proportion of rural households suffer from malnutrition and other diseases related to nutrition. According to FAO (2011), Women are frequently victims of hunger. They are significant to defeating hunger and in maintaining the three pillars of food security (food production, economic access to available food, and nutritional security) (IFPRI, 1995). According to FAO, rural women are responsible for half of the world's food production and have a prominent role in agriculture at all levels, in home, farm level and export crop production (Oluwatayo, n.d.). Traditionally, food security is viewed as having three dimensions (spatial, temporal, and gender) (FCND, 1999). The place of gender is fundamental in guaranteeing food security at all levels. The word 'gender' refers to the socially constructed roles, behaviours, activities and attributes that a given society considers appropriate for women and men (WHO, 2014, COE, n.d and Ogatoet al., 2009). It relates to the social meaning of biological sex differences (Ogatoet al., 2009, Oluwatayo, n.d). The distribution of productive resources and the enjoyment of rights and entitlements within the family and the public are influenced by gender (DAW, 1999). This in turn influences the food security status of individual. According to FAO (2009), Women made up about 43 percent of the agricultural labour force in developing countries. Women in agriculture and rural areas across regions have less access than men to productive resources and opportunities. FAO (2011) confirms the existence of a gender gap for many assets, inputs and services, including land, livestock, labour, education, extension and financial services, and technology. Despite this, evidence from Africa, Asia and Latin America consistently shows that families benefit when women have greater status and power within the households, they spend more of it than men do on food, health, clothing and education for their children (FAO, 2014b). This has positive implications for immediate well-being, long-run human capital formation and economic growth through improved health, nutrition and education outcome (FAO, 2011).

Furthermore, improving women's health and nutrition, and their access to education and training opportunities, enhances their human capital as an input to ensuring individual and household food security 
(USAID, 2000). In general, food security exist when all people at all-time have physical and economic access to sufficient, safe and nutritious food to meet their needs and food preferences for an active and healthy life (BusieMaziya-Dixon, 2014, CIRAD, 2014). However, when people lack secure access to sufficient amounts of safe and nutritious food for normal growth and development, and an active and healthy life, food insecurity abounds" (UN. Org. FAO 2011).

According to FAO (2003) rural household adopt different coping strategies to ensure that they are food secure. One of the most common methods for identifying food-insecure households or regions is to look at the frequency and types of coping strategies (The Open University, n.d). Coping strategies are social responses used to offset threats to a household's food and economic resources in times of hardship. Coping strategies that mark the severity of food insecurity is classified into four different stages (The Open University, n.d, Tulane ed. n.d).

The first stage is marked by the initial shortage of food, or inability to provide sufficient quantities of food to all members of the household. The stage adaptation strategies are marked by changes in diet and frequency of meals per day, rationing of food consumed, inter- household transfers and loans, gathering wild foods, increased petty commodity production (firewood, charcoal, etc.), seeking daily labour, Diversifying activities and working for long hours and consequent quick sales of productive assets to meet the short falls.

The second stage of food insecurity is marked by the sale of non-productive assets such as Jewellery, sales of non-productive livestock such as goats and chickens, insurance assets, credit or loans from merchants, temporary migration for work or land, skipping meals for entire days and withdrawing children from school.

The third stage involves the sales of productive assets and the shift of number one priority from asset preservation to food consumption. The indicators are sales of- all livestock, productive equipment, mortgage of land redistribution of children and Migration.

The last stage is referred to as distress strategies. At this stage, The household no longer exists as it once did, as some members of the household might have migrated permanently from their abode, the children might engage in begging for food/resources or the entire households completely dependent on external aids (The Open University, n.d, Tulane ed. n.d).

Despite the literature on different coping strategies for food security, there are few evidences on different strategies employed by gender in coping with food insecurity. It is on this note that this research work is carried out to investigate gender differentials in rural households' food security coping strategies in South-west, Nigeria. Some of the research questions being investigated include:

- What is the gender distribution ofrural households' food security status in south-west Nigeria?

- How do men/women cope with food insecurity?

- Is there any significant difference in the coping strategies adapted on gender basis?

- If yes, what are they?

- How could male and female genders in South-west Nigeria ensure a sustainable food security status?

\section{Methodology}

The study was carried out in South-western Nigeria. A multi stage sampling technique was used in the study. The first stage involves a random selection of three out of six states in the region. The states selected are Ondo, Osun and Ekiti states. The second stage involves a random selection of three Local Government Areas (LGAs) from each state and the subsequent selection of two communities from each LGA. The last stage involves a purposive selection of seven male and seven female genders from each community. This makes a total of two hundred and fifty two respondents. The study evolves the use of a well-structured questionnaire, open discussions, interviewsand physical observation for collecting primary data. Descriptive Statistics such as frequency counts and percentages were employed in describing the socio economic characteristics of the respondents while Food Poverty Line was constructed to categorize the households into food secure and nonfoodsecure groups using the two-third mean per-capita food consumption expenditure (World Bank, 1986; IFPRI 2001; Oluwatayo, 2005) as the benchmark. Households whose mean consumption expenditure falls below thefood poverty line are regarded as being food insecure while those with their expenditure above the benchmark arefood secure.Per-capita Food Consumption Expenditure (PCFEXP) = Food Consumption Expenditure/Household Size

Total Per-capita Food Consumption Expenditure (TPCFEXP) = Summation of PCFEXP

Mean TPCEXP $=$ TPCEXP $/$ Total Number of Households $=$ MTPCEXP

Food Poverty Line $(\mathrm{FPL})=2 / 3 *$ MTPCEXP

Also, Coping Strategies Use Index (CSUI) was employed to access the extent of use of the copingstrategies by these households. Seventeen coping strategies were identified using the CARE / WFP (2003) Coping Strategy Index (CSI) and modified to include local content after the pre-survey. The coping strategies index are classified into six groups namely: consumption, expenditure, income, spiritual, external aids and migration strategies 
Consumption strategies include: reducing the quantity of meals taken daily, consume less expensive food, reduce the number of times to eat, consume reserved seed stock, begging for food/ resources and attending parties.

Expenditure strategies include: borrowing money from friends/relatives; rationing money had to buy prepared food, withdrawing children from school.

Income strategies include: Sales of asset such as land, jewelries, Engage children in hawking, Occupation diversification/ engage in multiple jobs.

Spiritual strategy include: fasting and praying.

Migration strategies include: migrating to cities and towns to find work.

External aids: Depending on external aids

Theformula used to obtain the CSI score was adapted from Islam and Kashem (1999) that estimated the useof Ethno-veterinary medicine in livestock management and rearing. This was modified to obtain the CSUI as:CSUI $=\mathrm{N} 1 \mathrm{X}+\mathrm{N} 2 \mathrm{X}+\mathrm{N} 3 \mathrm{X}+\mathrm{N} 4 \mathrm{X}$

Where:

CSUI = Coping Strategies Use Index

$\mathrm{N} 1=$ Number of households using a particular CSI frequently

$\mathrm{N} 2=$ Number of households using a particular CSI occasionally

N3= Number of households using a particular CSI rarely

$\mathrm{N} 4=$ Number of households not using any of the Coping strategies.

The CSUI was used in ranking order to reflect the relative position of each of the CSI in terms of their use.

\section{Results and Discussion}

Data in table 1 shows the socio-economic characteristics of the respondents.

Age: Most (75\%) of the male gender were below 50 years of age while half of the female was above 50 years of age. The mean age of the male respondents was 45 years while that of the female gender was 50years. The result indicates that the female were on the average older than the male. The older female respondents might likely find it more difficult to cope with food insecurity than the male counterparts.

Marital Status: The marital status indicates that most of the male respondents $(65.08 \%)$ were married as against 58.73 percent of the female respondents. There were more divorced/separated, widowed and cohabiting women than men. The implication of this is that these groups of females solely bear the burden of providing food for their households. This might affect the food security status, as single, widowed, and cohabiting women might find it difficult to access credit facilities and productive resources than men. Hence, policies aimed at improving the food security status of the people in South Western Nigeria should take cognizance of the different groups rather than treating women as a homogeneous group.

Household size: Above 80 percent of the male respondents have more than five members in their households, while about 58 percent of the female respondents have more than five members in their households. It shows that although most of the respondents have large household sizes, the male respondents have larger household sizes than the females. Households with large family sizes are expected to spend a good proportion of their income on meeting the basic needs of life such as food, clothing, and shelter. Ability to meet the basic needs will worsen in situations whereby the households are headed by females. Large household sizes are expected to have a negative effect on food security.

Educational Status: About 84.12 percent of the male respondents had at least Secondary education compared to 71.43 percent of the females; an indication that the males are more literate than the females. High educational status is expected to predispose the respondents to innovations and better positions to cope with food insecurity challenges.

Primary Occupation: Table 1 also reveals that most of the male respondents $(54.76 \%)$ were farmers, when compared to 42.06 percent of the female respondents. Other major occupations engaged in by the male gender include; teaching $(23.02 \%)$ and Civil servants (14.29\%) while a few were mechanics and fashion designers. Other major occupations of the female respondents include; teaching (26.08\%), civil servants (13.49) and petty trading $(11.91 \%)$ and fashion designing

The study shows that both the male and female genders have three common occupations- farming, teaching and civil servants. The heterogeneity of occupation of the respondents as indicated in the study contradicts the assumptions of the rural people as a homogeneous group (Ekong, 1988). The occupational diversity is a reflection of the different needs and interests of the people and the need to develop different strategies to address them. 
Gender Differentials In Rural Household Food Security coping Strategies in South West, Nigeria

Table 1: Distribution of Socio-economic characteristics of the selected Respondents

\begin{tabular}{|c|c|c|c|c|}
\hline \multirow[t]{2}{*}{ Respondent characteristics } & \multicolumn{2}{|l|}{ Male } & \multicolumn{2}{|l|}{ Female } \\
\hline & frequency & Percentage & Frequency & Percentage \\
\hline $\begin{array}{l}\text { Age } \\
<30 \\
31-40 \\
41-50 \\
51-60 \\
>61 \\
\text { Total } \\
\end{array}$ & $\begin{array}{l}15 \\
38 \\
41 \\
18 \\
14 \\
126 \\
\end{array}$ & $\begin{array}{l}11.9 \\
30.2 \\
32.5 \\
14.3 \\
11.1 \\
100 \\
\end{array}$ & $\begin{array}{l}18 \\
45 \\
24 \\
26 \\
13 \\
126 \\
\end{array}$ & $\begin{array}{l}14.3 \\
35.7 \\
19.05 \\
20.63 \\
10.32 \\
100 \\
\end{array}$ \\
\hline $\begin{array}{l}\text { Marital status } \\
\text { Single } \\
\text { Married } \\
\text { Divorced/separated } \\
\text { Widowed } \\
\text { Co-habiting } \\
\text { Total } \\
\end{array}$ & $\begin{array}{l}11 \\
82 \\
15 \\
08 \\
10 \\
126 \\
\end{array}$ & $\begin{array}{l}8.73 \\
65.08 \\
11.90 \\
6.35 \\
7.94 \\
100 \\
\end{array}$ & $\begin{array}{l}05 \\
74 \\
20 \\
12 \\
15 \\
126\end{array}$ & $\begin{array}{l}3.97 \\
58.73 \\
15.87 \\
9.52 \\
11.91 \\
100 \\
\end{array}$ \\
\hline $\begin{array}{l}\text { Household size } \\
1-5 \\
6-10 \\
11-15 \\
>15 \\
\text { Total } \\
\end{array}$ & $\begin{array}{l}24 \\
54 \\
37 \\
11 \\
126 \\
\end{array}$ & $\begin{array}{l}19.05 \\
42.86 \\
29.37 \\
8.73 \\
100 \\
\end{array}$ & $\begin{array}{l}54 \\
39 \\
25 \\
08 \\
126 \\
\end{array}$ & $\begin{array}{l}42.86 \\
30.95 \\
19.84 \\
6.35 \\
100 \\
\end{array}$ \\
\hline $\begin{array}{l}\text { Educational status } \\
\text { Primary Education } \\
\text { Secondary Education } \\
\text { Tertiary Education } \\
\text { Non formal edu./ Adult literacy program } \\
\text { No formal education } \\
\text { Total }\end{array}$ & $\begin{array}{l}12 \\
48 \\
43 \\
15 \\
18 \\
126 \\
\end{array}$ & $\begin{array}{l}9.52 \\
38.09 \\
34.13 \\
\\
11.90 \\
14.29 \\
100.0 \\
\end{array}$ & $\begin{array}{l}20 \\
56 \\
24 \\
10 \\
16 \\
126 \\
\end{array}$ & $\begin{array}{l}15.87 \\
44.44 \\
19.05 \\
7.94 \\
12.70 \\
100.0 \\
\end{array}$ \\
\hline $\begin{array}{l}\text { Primary Occupation of Respondents } \\
\text { Farming } \\
\text { Teaching } \\
\text { Civil servant } \\
\text { Petty trader } \\
\text { Fashion designer } \\
\text { Mechanic } \\
\text { Artisan } \\
\text { Total }\end{array}$ & $\begin{array}{l}69 \\
29 \\
18 \\
0 \\
02 \\
03 \\
05 \\
126\end{array}$ & $\begin{array}{l}54.76 \\
23.02 \\
14.29 \\
0.00 \\
1.59 \\
2.38 \\
3.96 \\
100.0\end{array}$ & $\begin{array}{l}53 \\
34 \\
17 \\
15 \\
07 \\
0 \\
0 \\
126\end{array}$ & $\begin{array}{l}42.06 \\
26.98 \\
13.49 \\
11.91 \\
5.56 \\
0.00 \\
0.00 \\
100.0\end{array}$ \\
\hline
\end{tabular}

Source: Field Survey data, 2011

\subsection{Estimation of the Food Poverty Line [PPI]}

\section{Gender Distribution of Respondents by Food Poverty Status}

Figure 1 show that the male households were more food securethan the female households. This is expected because the socio- economic characteristics indicate a high percentage of single parents, divorced and cohabiting female respondents. These set of farmers might have less access to productive resources. More also, evidences abound that the female farmers produce less than the male farmers in developing countries. According to FAO (2011) the differences in male and female productivity in developing countries results from the gender gap in access to inputs. It confirms the FAO (2011) assertion that despite women comprises about 43 percent of the agricultural labour force in developing countries; they have less access than men to productive resources and opportunities. The food security status of the female gender could be upgraded if they have better access to essential resources and services, such as land, credit, and training (FAO, 2000). 


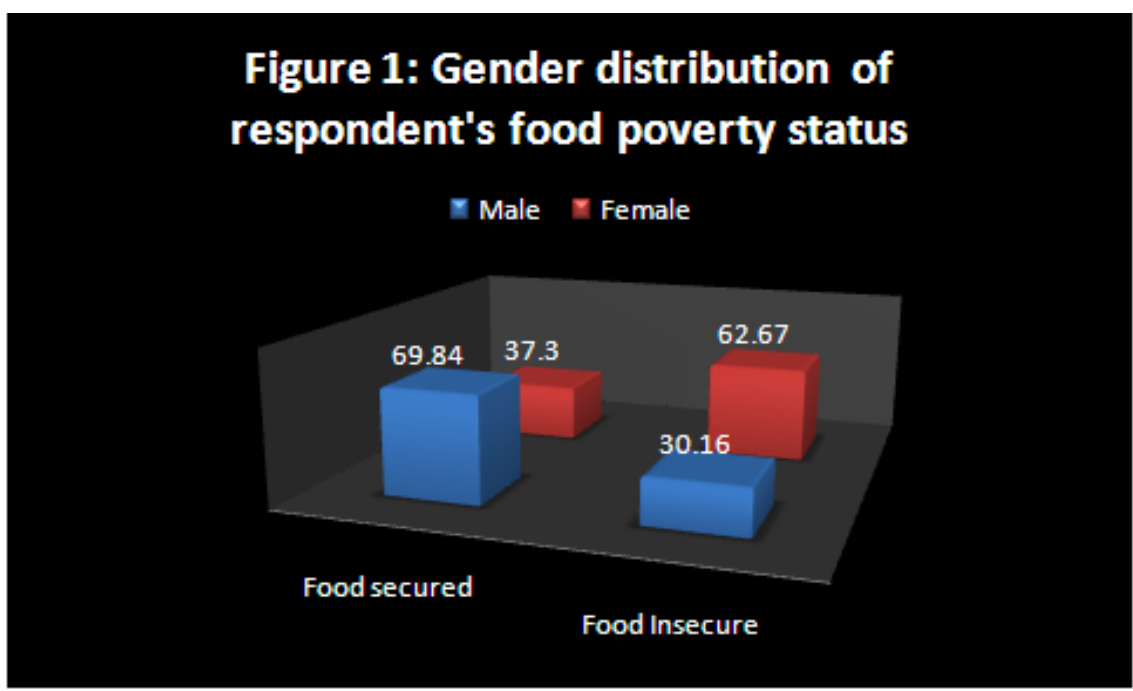

Source: Computed from survey data, 2010

Data in table 2 shows that the consumption of less expensive food had the highest CSI with a value of 272 and was ranked first among the male gender. This was followed by the consumption of reserved seed stock (CSI-242). Rationing money had to buy prepared food (CSI-227) came third, followed by migration to cities and towns and reduction in the quantity of meals taken (CSI-190 respectively) occupying the fourth position. Occupation diversification/ engage in multiple jobs (CSI-184) came sixth. Another food security coping strategies utilized by the male gender includes reduction in the number of time to eat (CSI-176), borrowing money from banks/cooperative (CSI-154) and friends/relatives (CSI-126). They also solve it spiritually through fasting and praying. All other variables recorded low percentages. The least coping strategies adopted by the male gender were attending parties, purchasing food on credits (CSI-29) and begging for feed / resources (CSI-4). It worth noting, that none of the male gender,depends on external aid as a food security coping strategy.

Considering the female gender, table 2 also shows that the consumption of less expensive food had the highest CSI value of 315. It occupies the first position, followed by occupation diversification/ engaging in multiple jobs (CSI-308). At the third and fourth position were the consumption of reserved seed stock (CSI-290) and purchase food on credit (CSI-288). Also, reduction in the number of time to eat (CSI-273) came fifth. Other strategies employed by the female gender includes sales of asset such as land, jewelries (CSI-250), borrowing money from friends/relatives (CSI-245) and engaging children in hawking (CSI-226). They also reduce the quantity of meals taken (CSI-222) as well as fasting and praying (CSI-210). The least food security coping strategy utilized was begging for food/ resources and migration to cities and towns.

Though the consumption of less expensive food was ranked first among both the male and female genders, there are wide variations in the food security coping strategies utilized. For instance, rationing of the money had to buy prepared food was one of the top coping strategies utilized by the male gender. It was among the least strategies utilized by the female gender. It might be because the female gender would not buy food for herself alone without considering the other members of the family. This supports the claim ofKabeer, (1990) that women throughout the world play multiple roles, as mothers, homemakers, producers and contributors to the family income and community organizers. It also confirms that women are more concerned about the general welfare of the family than men (FAO, 2011).

Also, the male gender migrates to cities and towns. Migration is not common among the female gender. It is men that migrate (Kabeer, 1990) as a coping strategy to food insecurity, leaving behind women and children. Greater male mobility increases the vulnerability of women in both Africa and Asia (Kabeer, 1990).

The study shows that the female were more hit by food insecurity than their male counterparts. The summation of the coping strategy index adopted by the female gender was higher than that of the male gender. This is in line with the findings of Nickanor (2013) that women and children in South Africa were most vulnerable to food insecurity in South Africa. Also, Louise and Cullen, (2011) reiterated that women are primary caretakers of children, responsible for the maintenance of the household andfoodpreparation. Women with less purchasing power than men are particularly vulnerable to resorting to risky coping strategies, especially when they have low education and few economic opportunities 
Gender Differentials In Rural Household Food Security coping Strategies in South West, Nigeria

Table 2. Food Securitycopping Strategies

\begin{tabular}{|c|c|c|c|c|c|c|c|c|c|c|c|c|c|c|}
\hline & \multicolumn{7}{|c|}{ MALE } & \multicolumn{7}{|c|}{ FEMAIE } \\
\hline $\begin{array}{l}\text { COPNG } \\
\text { STRATEGY }\end{array}$ & $\begin{array}{c}\text { Frequently } \\
\text { used (3) }\end{array}$ & $\begin{array}{c}\text { Occasionally } \\
\text { used (2) }\end{array}$ & \begin{tabular}{|c|} 
Rarely \\
Used \\
$(1)$ \\
\end{tabular} & \begin{tabular}{|c|} 
Not \\
used \\
$(0)$ \\
\end{tabular} & $\mathrm{CSI}$ & $\begin{array}{c}\% \text { of } \\
\text { Household }\end{array}$ & Rank: & $\begin{array}{c}\text { Frequently } \\
\text { used (3) }\end{array}$ & $\begin{array}{c}\text { Occasionally } \\
\text { used (2) }\end{array}$ & $\begin{array}{c}\text { Rarely } \\
\text { Used } \\
\text { (1) }\end{array}$ & $\begin{array}{c}\text { Not } \\
\text { used } \\
(0) \\
\end{array}$ & $\mathrm{CSI}$ & $\begin{array}{c}\% \text { of } \\
\text { Household }\end{array}$ & Rank \\
\hline $\begin{array}{l}\text { Reduce the } \\
\text { quantity of Meals } \\
\text { taken }\end{array}$ & 7 & 69 & 31 & 19 & 190 & 8.61 & 4 & 5 & 96 & 15 & 9 & 222 & 7.49 & 9 \\
\hline $\begin{array}{l}\text { Consume less } \\
\text { expensive food }\end{array}$ & 50 & 56 & 10 & 10 & 272 & 12.33 & 1 & 67 & 55 & 4 & 0 & 315 & 10.3 & 1 \\
\hline $\begin{array}{l}\text { Reduce the number } \\
\text { of time to eat }\end{array}$ & 8 & 62 & 28 & 28 & 176 & 7.98 & 7 & 56 & 40 & 25 & 5 & 273 & 8.88 & 5 \\
\hline $\begin{array}{l}\text { Sale of asset such } \\
\text { as land, jewelleries }\end{array}$ & 6 & 16 & 24 & 80 & 74 & 3.35 & 12 & 45 & 44 & 27 & 10 & 250 & 8.44 & 6 \\
\hline $\begin{array}{l}\text { Borrow money } \\
\text { from } \\
\text { friends/relatives }\end{array}$ & 18 & 19 & 34 & 55 & 126 & 5.72 & 9 & 55 & 30 & 20 & 21 & 245 & 8.27 & 7 \\
\hline $\begin{array}{l}\text { Rationing money } \\
\text { had to buy } \\
\text { prepared food }\end{array}$ & 54 & 26 & 13 & 33 & 227 & 10.29 & 3 & 5 & 35 & 60 & 26 & 145 & 4.9 & 12 \\
\hline $\begin{array}{l}\text { Withdraw children } \\
\text { from school }\end{array}$ & 0 & 18 & 19 & 89 & 55 & 2.49 & 13 & 0 & 10 & 25 & 91 & 45 & 1.52 & 13 \\
\hline $\begin{array}{l}\text { Engage children in } \\
\text { hawking }\end{array}$ & 0 & 12 & 32 & 82 & 100 & 4.53 & 11 & 45 & 30 & 31 & 20 & 226 & 7.63 & 8 \\
\hline $\begin{array}{l}\text { Solve it spiritually } \\
\text { by fasting and } \\
\text { praying }\end{array}$ & 08 & 29 & 35 & 54 & 117 & 5.3 & 10 & 50 & 20 & 20 & 36 & 210 & 7.09 & 10 \\
\hline $\begin{array}{l}\text { Consumption of } \\
\text { reserved seed stock }\end{array}$ & 63 & 20 & 11 & 32 & 240 & 10.88 & 2 & 70 & 35 & 10 & 11 & 290 & 9.12 & 3 \\
\hline $\begin{array}{l}\text { Migration to cities } \\
\text { and towns }\end{array}$ & 7 & 69 & 31 & 19 & 190 & 8.61 & 4 & 0 & 0 & 0 & 126 & 0 & 0 & 16 \\
\hline
\end{tabular}

\section{Summary, Conclusion And Recommendations}

\section{Summary}

The study was carried out to investigate gender differences in rural households' food security coping strategies in South-Western Nigeria. A multi stage sampling technique was used in selecting three states, nine Local Government Areas, 18 communities and 252 respondents utilized for the study. The study evolves the use of a well-structured questionnaire to elicit information. Descriptive Statistics such as frequency counts and percentages were employed in ascertaining the socio -economic characteristics of the respondents. Also, Food Poverty Line was constructed to categorize the households into food secure and non-food secure group using the two-third mean per-capita food consumption expenditure as the benchmark. Households whose mean consumption expenditure falls below the food poverty line are regarded as being food insecure while those with their expenditure above the benchmark are food secure. Seventeen coping strategies were identified using theCARE / WFP (2003) Coping Strategy Index (CSI) and modified to include local content after the pre-survey. The coping strategies index is classified into six groups: consumption, expenditure, income, spiritual, external aids and migration strategies.

The result shows that the mean age of the male respondents was 45 years while that of the female gender was 50years. The females were on the average older than the male. Most of the male respondents (65.08\%) were married as against 58.73 percent of the female respondents. There were more divorced/separated, widowed and cohabiting women than men. Although most of the respondents have large household sizes, the male respondents have larger household sizes than the females. While a higher proportion of both genders was literate, the literacy level of the male gender was higher than that of the females. Most of the male respondents (54.76\%) were farmers, when compared to 42.06 percent of the female respondents. The male and female genders have three common occupations, which are farming, teaching and civil servants. However, some of the female respondents engaged in petty trading and fashion designing. The heterogeneity of occupation of the respondents as indicated in the study contradicts the assumptions of the rural people as a homogeneous group. The occupational diversity is a reflection of the different needs and interests of the people and the need to develop different strategies to address them. The male households were more food secure $(69.84 \%)$ than the female households (37.3\%). Though the consumption of less expensive food was ranked first among both the male and female genders, there are wide variations in the food security coping strategies utilized. While rationing money had to buy prepared food and migration to cities and towns were among the top coping strategies utilized the male gender, they were among the least strategies utilized by the female gender. Coping strategies mostly used by the female gender include occupation diversification/ multiple jobs, purchase food on credit and the sale of assets such as land and jewelries. The summation of the coping strategy index adopted by the female gender was higher than that of the male gender. The female genders were more hit by food insecurity than the male counterparts. 


\section{Conclusion}

The female was on the average older than the male. The females were in several marital status categories than the males. There were more divorced/separated, widowed and cohabiting women than men. The males have larger household sizes and were more literate than the females. Both the male and female genders engaged in heterogeneous occupation. Both male and female genders have three common occupations, which are farming, teaching and civil servants. However, some of the females engaged in petty trading and fashion designing. The male households were more food secure than the female households. The food security status of the female gender could be enhanced if they have better access to essential resources and services, such as land, credit, and training.

A good proportion of both male and female genders were food insecure. Though the consumption of less expensive food was ranked first among both the male and female genders, there are wide variations in the food security coping strategies utilized by them. The summation of the coping strategy index adopted by the female gender was higher than that of the male gender. The female genders were more hit by food insecurity than the male counterparts.

\section{Recommendations}

Based on the findings of the study, the following recommendations are made. Policies aimed at improving rural households' food security status in South-Western Nigeria should take cognizance of the diversity of the female gender marital status groups rather than treating women as a homogeneous group. Efforts should be made to educate the rural dwellers on the necessity to maintain a small family size in order to reduce poverty and ensure food security. There is a need to consider the occupational diversity of the people and develop strategies to address them. Special attention should be paid to the food insecurity status among the female gender by NGOs and Governmental Organizations. Access to productive resources and services of the female gender should be enhanced. There is a need to generate policies that will address gender issues in order to reduce food insecurity in Nigeria

\section{References}

[1]. BusieMaziya-Dixon (2014).Sustainable Innovations in Food Production through Biotechnology. http://foodbusinessng.org/?p=115

[2]. CARE / WFP (2003). The Coping Strategies Index: Field Methods Manual. Nairobi: CARE and WFP.

[3]. CIRAD (2014). Food security - CIRAD - Cirad- Agricultural Research for Development. La rechercheagronomique pour .Retrieved from http://www.cirad.fr/en/research-operations/research-topics/food-security/what-s-cirad-doing.

[4]. Division of the Advancement of Women-DAW (1999) World Survey on the Role of Women in Development:Globalization, Gender and Work. Department of Economic and Social Affairs. New York: United Nations.

[5]. Ekong E. Ekong: (1988): An introduction to Rural Sociology. Jumak Publisher Ltd, Ring road Ibadan

[6]. Food Consumption and Nutrition Division- FCND (1999) Technical Guides for Operationalising Household Food Security in Development Projects. Washington: International Food Policy Research Institute.

Food and Agriculture Organization (FAO), http://www.fao.org/sofa/gender/key-facts/en/.

[7]. FAO, (2009).Men and women in agriculture: closing the gap: Did you know? http://www.fao.org/sofa/gender/did-you-know/en/.

[8]. Food and Agriculture Organization (FAO, 2009): Food Security And Agricultural Development In Sub-Saharan Africa. Building a case for more public support WORKING PAPER No. 01/Eftp://ftp.fao.org/docrep/fao/009/a0788e/a0788e.pdf.

[9]. FAO (2011): The state of Food and Agriculture. Women in Agriculture: Closing the gender gap for development. http://www.fao.org/docrep/013/i2050e/i2082e00.pdf.

[10]. FAO (2014a). News article on Global food hunger

[11]. http://www.fao.org/news/story/en/item/161819/icode/.

[12]. FAO (2014b). Men and women in agriculture: closing the gap: Key facts. http://www.fao.org/sofa/gender/key-facts/en/.

[13]. International Fund for Agricultural Development ( IFAD, 2013). Report 2013- International Fund for Agricultural Developmentwww.ifad.org/pub/ar/2013/e/print.pdf.

[14]. IFPR1 (1995). Women: The Key to Food Security - Food Policy Report (IFPRI; 1995; 28 pages) http://collections.infocollections.org/ukedu/uk/d/Jh0151e/3.html

[15]. Islam, M. M. and M. A. Kashem (1999) Farmers use of Ethno-veterinary Medicine (EVM) in the rearing and management of livestock: An Empirical Study in Bangladesh, Journal of Sustainable Agriculture, Vol. 13, No.4 pp. 39-56.

[16]. Louise C Ivers and Kimberly A Cullen(2011) Food insecurity: special considerations for womenfile:///C:/Users/DUPE/Documents/Australian\%20documents/CSI/Am\%20J\%20Clin\%20Nutr-2011-Ivers-1740S-4S.pdf.

[17]. Maxwell, D., C. Ahiadeke, C. Levin, M. Armar-Klemesu, S. Zakariah, and G. M. Lamptey. 1999.

[18]. Alternative food security indicators: Revisiting the frequency and severity of "coping strategies."

[19]. Food Policy 24 (4): 411-429.

[20]. Ndeyapo M. Nickanor (2013). Women and Urban Food Insecurity in Southern Africa http://www.africaportal.org/sites/default/files/Africa\%20Portal\%20Backgrounder\%20No\%2055.pdf

[21]. Ogato G.S, E. K. Boon and J. Subramani (2009). Gender Roles in Crop Production and Management Practices: A Case Study of Three Rural Communities in Ambo District, Ethiopia. Journal of Human Ecology. Vol. 27. Pp 1-20

[22]. Oluwatayo, I. B. (2005) The Effect of Poverty on Children's Upbringing in Ibadan, Oyo State, Nigeria: A Case

[23]. Study of Abadina Community. Multidisciplinary Journal of Empirical Research Vol. 2, No. 1, pp. 21 - 30.

[24]. Oluwatayo (n.d). Gender Considerations In Decision Making In Rural Nigeria .Implications On

[25]. Households' Food Security In Ekiti State.. (n.d.). Retrieved from http://erd.eui.eu/media/oluwatayo.pdf

[26]. The Open University (n.d). Household Food Security: View as single page. (n.d.). Retrieved from http://www.open.edu/openlearnworks/mod/oucontent/view.php?id=321\&printable=1.

[27]. Tulane University (ND). Food security Home Coping Strategies: Stages 1-4

[28]. http://www.tulane.edu/ panda2/FS/Coping\%20strategy/stages/stages.htm. 
[29]. United Nations Economic Commission for Africa(UNECA, 2012): Status of Food Security in Africa http://www.uneca.org/sites/default/files/page_attachments/3._cfssd-8-0032-ore-status_of_food_security_in_africa_2012.pdf.

[30]. United Nations Resources for Speakers on Global Issues (n.d.). What is Hunger.( Retrieved from http://www.un.org/en/globalissues/briefingpapers/food/whatishunger.shtml.

[31]. USAID (2000).Improving Household Food Security: Institutions, Gender and Integrated Approaches. http://hubrural.org/IMG/pdf/basissem9911_panel3c.pdf.

[32]. Shannon Senefeld and Ken Polsky (nd) Chronically Ill Households, Food Security, and Coping Strategies in Rural Zimbabwe http://www.ifpri.org/sites/default/files/pubs/pubs/books/oc50/oc50ch07.pdf. pp 129-139

[33]. KabeerNaila (1990). Homen, Household $\quad$ Food $\quad$ Security Strategieshttp://www.unsystem.org/scn/archives/npp06/ch22.htm.

[34]. (2012, 03). The Global Food Security Crisis. StudyMode.com. Retrieved 03, 2012, from http://www.studymode.com/essays/TheGlobal-Food-Security-Crisis-938088.html

[35]. Council of Europe (COE, n.d) Supporting Gender Equality Rapporteurs (GERs) in their role manual http://www.coe.int/t/dghl/standardsetting/equality/02_GenderEqualityProgramme/GER/Documents/GERs\%20training\%20Manual $\% 2029 \% 201 \% 202014 . \mathrm{pdf}$

[36]. World Bank (1986) Poverty and Hunger: Issues and Options for Food Security in Developing Countries. Washington, D. C., USA

[37]. World Health Organization (2014). Gender, Women and health. http://www.who.int/gender/whatisgender/en/ 